\title{
ESSENTIALISM MAKES FOR STRANGE BEDMATES: THE SUPREME COURT CASE OF J.A. AND THE INTERVENTION OF L.E.A.F.
}

\author{
Richard Jochelson" \\ Kirsten Kramar**
}

In the recent case of $\mathrm{R} . \mathrm{v} \mathrm{J} . \mathrm{A}$, the majority of the Supreme Court of Canada determined that an unconscious person could not consent in advance to sexual touching. This paper reviews the majority reasoning and questions whether the intervention of the Women's Legal Education and Action Fund [LEAF] penetrated the reasoning. The majority couched its reasoning in the interpretive tenets of judicial conservatism. Yet this conservatism aligned with the equality-based submissions of LEAF. Moments of such converging ideologies are relatively unique in the jurisprudence. This convergence is compared with a notable historical moment of convergence in the development of indecency and obscenity law in Canada. This time, however, $L E A F$ 's rationales are more likely to meet little in the way of academic or activist critique because of the changing nature of identity politics in Canada.

Dans la récente affaire R. c. J.A., la majorité des juges de la Cour suprême du Canada a établi qu'il ne peut y avoir consentement à l'avance à des actes sexuels commis pendant qu'une personne est inconsciente. Le présent article passe en revue le raisonnement de la majorité et examine si l'intervention du Fonds d'action et d'éducation juridiques pour les femmes (FAEJ) a influencé ce raisonnement. La majorité des juges a fondé son raisonnement sur les principes d'interprétation $d u$ conservatisme judiciaire. Or, ce conservatisme allait dans le sens des arguments du FAEJ en matière d'égalité. Un tel degré de convergence d'idéologies est relativement rare dans la jurisprudence. La convergence dans cette affaire est comparée à celle, notable et historique, qu'on a connue lors de l'élaboration de la législation sur l'indécence et l'obscénité au Canada. Cette fois-ci, cependant, les motifs du FAEJ vont probablement être peu critiqués par les milieux universitaire et militant, étant donné l'évolution de la politique identitaire au Canada.

\footnotetext{
University of Winnipeg, Department of Criminal Justice

** University of Winnipeg, Department of Sociology
} 


\section{INTRODUCTION \& OVERVIEW}

In the end, we are left with this. Parliament has defined sexual assault as sexual touching without consent. It has dealt with consent in a way that makes it clear that ongoing, conscious and present consent to "the sexual activity in question" is required. This concept of consent produces just results in the vast majority of cases. It has proved of great value in combating the stereotypes that historically have surrounded consent to sexual relations and undermined the law's ability to address the crime of sexual assault. In some situations, the concept of consent Parliament has adopted may seem unrealistic. However, it is inappropriate for this Court to carve out exceptions when they undermine Parliament's choice. In the absence of a constitutional challenge, the appropriate body to alter the law on consent in relation to sexual assault is Parliament, should it deem this necessary.

Majority decision in J.A. per Chief Justice McLachlin

On May 27 2011, just three days before the Canadian Law and Society Association was hosting a panel on the case at its annual meeting, ${ }^{2}$ the Supreme Court of Canada released its decision in the R. v J.A. case. The case involved an accused who allegedly choked his partner into unconsciousness and proceeded to engage in sexual acts with her both while she was unconscious, and subsequently when she regained consciousness. While originally, the complainant had claimed she did not consent, she later recanted that allegation stating that she was using the claim as a threat to seek custody of their son. The trial court still found that sexual assault had occurred. ${ }^{3}$ While the Ontario court of Appeal disagreed, ${ }^{4}$ the Supreme Court reinstated the conviction. The Supreme Court of Canada was statutorily limited to consider only one issue in the case "whether consent for the purposes of sexual assault requires the complainant to be conscious throughout the sexual activity." The majority found that consciousness was a condition precedent to consensual sex in Canada and that "[i]t is not possible for an unconscious person to satisfy this requirement, even if she expresses her consent in advance."

The panel at the CLSA meetings, entitled, Interrogating R. v. J.A.: Sex, Violence and Consent, was led by three notable Canadian socio-legal academics in the area of sexuality and the law: Karen Busby, Lise Gotell and Elaine Craig. The panel provided an interesting analysis of the J.A. case, but most striking was their

$R v J A, 2011 \mathrm{SCC} 28$ at para. 65 [“JA"].

2 K. Busby, E. Craig \& L. Gotell, "Interrogating R. v J.A.: Sex, Violence and Consent” (Paper delivered at the Canadian Law and Society Association Annual Meeting, Coasts and Continents: Exploring People and Places, University of New Brunswick, Fredericton, May 28-June 1, 2011) [CLSA].

Ontario Court of Justice, 2008 ONCJ 195 (CanLI) (“ONCJ”).

Ontario Court of Appeal, 2010 ONCA 226, 100 O.R. (3d) 676 (“ONCA”).

$J A$, supra note 1 at para 21.

Ibid at para 66. 
unanimity that the case continued a Supreme Court jurisprudence that valued the sexual integrity of women; that had absorbed the feminist intervention of Canada's leading legal activist feminist organization, the Women's Legal Education and Action Fund [LEAF], and that had reached the only possible decision that could support the values of sexual integrity of women in the context. ${ }^{8}$

Certainly, the universality inherent in the panel's assertion that the interests of women were upheld by the Court was echoed by the posting on LEAF's website. Under the "Litigation" thumbnail, you will see, in bright type set, the banner "LEAF Victory". ' Click on the link and you will be led to a page that informs the reader that the Supreme Court "agreed with LEAF's arguments as described below: consent must be active and ongoing, and cannot occur whilst a woman is unconscious."

LEAF's claims that the Court had adopted its arguments in the case are bolstered by scrutinizing the thin list of factums that appeared before the Supreme Court in the case. The only other intervener that placed a factum before the Court was the Attorney General (AG) of Canada, and its factum largely spoke to the technicalities of the consent regime ${ }^{11}$ under the Criminal Code of Canada. ${ }^{12}$ On the other hand, LEAF's factum makes a convincing case that the Criminal Code "must be interpreted and applied consistent with Women's Charter rights and with their lived realities."

In many ways, how one reads the Supreme Court's decision, can elucidate whether the Court sees itself as subscribing to the philosophy of the identity politics issues that appeared before it via the LEAF factum, or views itself as guardian of the legislative impetus of Parliament, as suggested in the factum of the AG. ${ }^{14}$ Reading a Supreme Court decision for this purpose can yield interesting

7 LEAF has intervened in over 150 cases in Canada, providing an account of equality rights for women in these cases. Its website proclaims that:

LEAF litigates and educates to strengthen the substantive equality rights of women and girls, as guaranteed by the Charter of Rights and Freedoms. Year after year LEAF is working to gain intervener status at the Supreme Court of Canada. Our history includes intervention on hundreds of cases where interpretation of the law promises to increase or decrease the substantive equality of women and girls. LEAF also advances public understanding of women's equality rights through education programs administered by its branches and through its speakers' bureau.

online: LEAF <http://leaf.ca/about-leaf/history/>.

8 CLSA, supra note 2.

9 Women's Legal Education and Action Fund, online: LEAF < http://leaf.ca/>.

10 "Most recent or active cases" online: LEAF $<$ http://leaf.ca/legal-issues-cases-and-lawreform/active-cases/>.

$11 R v J A, 2011$ SCC 28 (Factum of the Intervener, Attorney General of Canada). Date of Publication 2010 [AG Factum].

12 R.S.C. 1985 , c-C-46 [“Code"].

$13 R v J A, 2011 \mathrm{SCC} 28$ (Factum of the Intervener, Women's Legal Education and Action Fund (LEAF)). Date of Publication 2010 at para. 32 [LEAF's Factum].

14 Here we are thinking of identity politics in a broader sense as those aspects of race, class, sexual orientation, disability, gender, or other dominance power relations and the potential intersection of these identities as a means of shaping legal change and social policy. For an interesting discussion see Nancy Fraser, "Heterosexism, Misrecognition, and Capitalism: Response to Judith Butler"(1998) 1:228 New Left Review 140; and Nancy Fraser, "Social Justice in the Age of 
conclusions about its philosophical predilections apart from the actual precedents it sets. Broadly speaking, this is the question that this paper interrogates. We ask whether the Supreme Court of Canada has indeed adopted LEAF's rationales in the Court's assertion that consciousness is a requirement for consensual sex. If indeed the Court has adopted LEAF's feminist logics, then the intervener has achieved more than just a victory of precedent. LEAF would have achieved a victory in informing Supreme Court analysis which would hold potential for its future interventions.

In order to interrogate these questions, the paper is organized into two distinct sections. In Part II, we explore the background of the case and review the Court's reasoning. In Part III of the paper, we explore the nature of LEAF's victory in this case - was its intervention a victory of precedent and/or discourse? In this part, we draw on an analogous previous intervention of LEAF in the context of obscenity and indecency law, and compare and contrast its intervention in J.A.

Ultimately we conclude that $J$.A. ought be construed as a cautious moment of celebration for LEAF. We urge caution in construing the J.A. case as a "victory" because we view the case as one written by a restrained Court in an era where its decisions have been tempered by its own political calculus, and one in which identity politics have faced unparalleled critique on the academic left (in addition to the usual critiques on the right). Thus, the J.A. decision may best be read as a case that leaves a complicated political legacy. ${ }^{15}$

\section{THE MAJORITY DECISION IN J.A.}

\section{A. J.A. - the Factual Background and Case History}

The facts in the case of J.A. were largely uncontested before the Supreme Court of Canada. The sexual assault took place between J.A. and his partner K.D. J.A., when in the course of sexual interactions, he began to choke K.D. rendering her unconscious for less than 3 minutes. While K.D. had previously complained to the police two months after the initial incident, by the time of trial she had recanted, testifying that she consented to the choking, and that she and J.A. had experimented with choking and unconsciousness on prior occasions. This time however, when she awoke, her hands were tied behind her back and a dildo was inserted in her anus. After she regained consciousness the dildo was removed, and vaginal intercourse ensued. ${ }^{16}$

Identity Politics: Redistribution, Recognition and Participation" in Grethe B Peterson, ed, Tanner Lectures on Human Values, vol 19(Salt Lake City: University of Utah Press, 1998) 1.

This paper cannot, in the allotted space, review the evolution of sexual assault law in Canada. For more comprehensive discussions of the evolution of sexual assault law see: Melanie Randall, "Sexual Assault Law, Credibility, and 'Ideal Victims': Consent, Resistance, and Victim Blaming" (2010)22 CJWL 397; Elizabeth Sheehy, ed, Sexual Assault Law, Practice and Activism in a Post Jane Doe Era vol 1 \& 2 (Ottawa: University of Ottawa Press, forthcoming ) ; Jennifer Koshan undertakes a meticulous review of the law of consent to sexual activity in Canada in "The Legal Treatment of Marital Rape and Women's Equality: An Analysis of the Canadian Experience" ( 2010) online: Equality Effect <http://theequalityeffect.org/resources.html>; see also Hilary Young, "R. $v$ A. (J) and the Risks of Advance Consent to Unconscious Sex" (2010) 14:3 Canadian Crim L Rev 273; Joanne H Wright, "Consent and Sexual Violence in Canadian Public Discourse: Reflections on Ewanchuk" (2001) 16:2 CJLS 173; Elizabeth Sheehy, "From Women's Duty to Resist to Men's Duty to Ask: How Far Have We Come?" (2000) 20:3 Canadian Women's Studies 98.

$16 J A$, supra note 1 at paras. 4-8. 
At the Ontario Court of Justice, K.D. was the only witness. Nicholas J. found that K.D. did not consent to the insertion of the dildo or alternatively that an unconscious person could not legally consent to sexual assault. ${ }^{17}$ At the Ontario Court of Appeal, the Court held that there was insufficient evidence on the matter of whether the complainant consented to the use of the dildo, but a majority concluded (with one dissenting justice opposed to the notion) that individuals could consent to unconscious sexual activity in advance. ${ }^{18}$ The lone dissenting opinion on a point of law provided a Crown appeal as of right on the issue of whether unconscious individuals could provide advance consent to sexual interactions. $^{19}$

\section{B. The Framework of Sexual Assault and the Court's Interpretation of Consent}

At the Supreme Court, the majority reviewed the framework of the law of sexual assault. In its decision it relied heavily on past case law (most notably the 1999 decision in $R . v$ Ewanchu $k^{20}$ ). It noted that a conviction of sexual assault under s. 271(1) of the Code required proof beyond a reasonable doubt of the actus reus and mens rea of the offence: the actus reus of the offense is established if an accused touches a complainant in a sexual way without her consent, and that consent is determined by the subjective state of mind of the complainant at the time of the activity. ${ }^{22}$ The mens rea of the offence required that the accused knew that the complainant was not consenting or was reckless of willfully blind as to the absence of consent:

The accused may raise the defence of honest but mistaken belief in consent if he believed that the complainant communicated consent to engage in the sexual activity. However(...)ss. 273.1(2) and 273.2 limit the cases in which the accused may rely on this defence. For instance, the accused cannot argue that he misinterpreted the complainant saying "no" as meaning "yes" ([citing ] Ewanchuk, at para. 51).

The majority reviewed the relevant sections of the Code. ${ }^{24}$ Section 265 of the Code states that:

17 Ibid at paras. 12-13; ONCJ, supra note 3 at paras. $41,44$.

18 Ibid., J.A. at paras. 15-16; ONCA, supra note 4 at para. 77.

19 s. 693(1)(a) of the Code; Ibid. J.A. at para. 21

20 [1999] 1 S.C.R. 330 [Ewanchuk]; The Ewanchuk case famously denied the defence of implied consent in sexual assaults, determined that mistake to consent would require an air of reality to be demonstrated by the accused and also affirmed that the victim's state of mind determined consent for the purposes of determining the physical element of the offence. For a detailed discussion see Elaine Craig. "Ten Years After Ewanchuk the Art of Seduction is Alive And Well: An Examination of The Mistaken Belief in Consent Defence" (2009) 13:3 Canadian Crim L Rev 247 [Craig, "Ten"].

21 By reference to an "objective" test.

$22 J A$, supra note 1 at para. 23 relying on Ewanchuk, supra note 20.

23 Ibid. JA at para. 24.

$24 \quad$ Ibid at para. 27. 


\section{5. (1) A person commits an assault when}

(a) without the consent of another person, he applies force intentionally to that other person, directly or indirectly;

(b) he attempts or threatens, by an act or a gesture, to apply force to another person, if he has, or causes that other person to believe on reasonable grounds that he has, present ability to effect his purpose; or

(c) while openly wearing or carrying a weapon or an imitation thereof, he accosts or impedes another person or begs.

(2) This section applies to all forms of assault, including sexual assault, sexual assault with a weapon, threats to a third party or causing bodily harm and aggravated sexual assault. ${ }^{25}$

Specific to sexual assault, s.273.1 provides for several limitations to the notion of consent. Under these provisions, consent requires voluntary agreement to engage in a particular sexual activity; however consent would be vitiated when it is expressed by the words or conduct of a person other than the complainant, the complainant lacks the capacity to consent, that the accused induces the complainant to engage in the activity by abusing a position of trust, power or authority, the complainant expresses, by words or conduct, a lack of agreement to engage in the activity or the complainant, having consented to engage in sexual activity, expresses, by words or conduct, a lack of agreement to continue to engage in the activity. ${ }^{26}$ The section goes on to state that the categories that constitute lack of consent are not closed. ${ }^{27}$

Further, the majority explained that the defence of mistaken belief in consent was limited by section 273.2 which provided that an accused could not rely on a mistaken belief that the complainant consented when that belief arose from an accused's self-induced intoxication, recklessness or wilful blindness. ${ }^{28}$ The section provides a further and affirmative requirement for an accused to take reasonable steps, in the circumstances known to the accused, to determine that the complainant was consenting.

The majority argued that a plain reading of these provisions indicated that it was Parliament's intention that sexual activity required conscious agreement to engage in each particular sexual encounter. ${ }^{30}$ The Court used the tenets of judicial interpretation to reach this decision noting that statutes must be read with attention paid to an analysis that was "textual, contextual and purposive" reading the

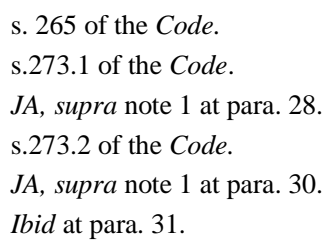


provisions as a "harmonious whole". ${ }^{31}$ It concluded that it was impossible on a harmonious reading of the Code to determine that "Parliament defined consent in a way that extends to advance consent to sexual acts committed while the complainant is unconscious." ${ }^{32}$ Drawing on the argument advanced by the AG of $\mathrm{Canada}^{33}$ the majority viewed Parliament as requiring that a complainant could only provide consent with an "operating mind" because a complainant must have a right to "revoke her consent at any time". ${ }^{34}$ The requirement in s.273.2(b) to take reasonable steps to ascertain consent provided further proof to the majority that the consent of a complainant must be an ongoing state of mind.

The majority also noted that this interpretation was consistent with its own jurisprudence. They noted that it had previously determined that the "only relevant period of time for the complainant's consent is while the touching is occurring" and that an actus reus based defence of implied consent was a legal impossibility. ${ }^{36}$ In terms of the mens rea defence of mistake as to consent, the majority noted that the accused cannot have made a reasonable mistake of fact about the consent if he did not take reasonable steps to ascertain consent, a matter which is impossible if one's partner was unconscious. ${ }^{37}$ The majority relied on the risk analytics of $R . v$ $E_{s a u^{38}}$. There, in the context of an allegation of sexual assault with an intoxicated complainant, Justice McLachlin (as she was then, and, in dissent) noted that:

The hypothetical case of a complainant giving advance consent to sexual contact before becoming unconscious does not constitute an exception [to the requirement of capacity to communicate agreement on the part of the complainant]. Consent can be revoked at any time. The person who assaults an unconscious woman cannot know whether, were she conscious, she would revoke the earlier consent. He therefore takes the risk that she may later claim she was assaulted without consent. ${ }^{39}$

The majority also argued that the unconsciousness would remove from the jurisprudence the notion that the only relevant temporal period for ascertaining consent is "while the touching is occurring"; thus unconsciousness renders the timing component irrelevant, negating a complainant's right to change her mind. ${ }^{40}$ In addition, unconscious sexual assault could be distinguished from unconscious but consensual physical intrusions such as "surgery" because medical intervention has its own exemptions enacted by Parliament and because pragmatic differences

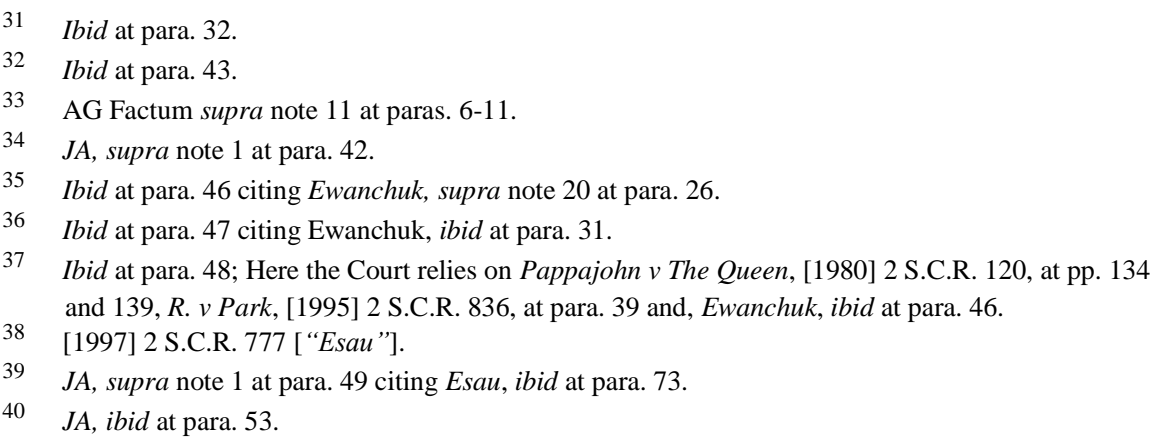


arise: "Surgical interventions are usually carefully planned, and appropriate consent is assured by consent forms and waivers - all to the end of limiting the risk of abuse. Such safeguards are rare, if perhaps non-existent, in the sexual arena." ${ }^{41}$ Similarly, other examples that relied on implied consent as a defence were rejected by the majority because of the specific nature of consent designed by Parliament in terms of sexual assault and in light of the Court's own jurisprudence. $^{42}$

The majority also extolled the virtues of the operating mind principle in refuting the concerns of arguments it had heard regarding the unintentional effects of the law of sexual assault on those who might kiss or fondle a sleeping partner. The majority noted that the risks of criminalization in such a case were acceptable for practical reasons: first, a defence of advance consent in such cases would be limited to situations where a complainant turned her mind to the exact touching at issue (and therefore would be useful on rare occasions), ${ }^{43}$ and second the unconscious person's wishes could be innocently misinterpreted by her partner "[t]he unconscious partner cannot meaningfully control how her person is being touched, leaving her open to abuse".

In addition, the majority was concerned with evidentiary pitfalls in accepting an advance consent rule: the complainant would have no way of knowing if the bounds of consent were exceeded and may never know whether they had been victimized. ${ }^{45}$ A defence of advance consent would ask the Court to overturn the intent of Parliament and require the Court to configure how that consent would be constructed, circumventing the role of Parliament. ${ }^{46}$ They ultimately concluded that:

The definition of consent for sexual assault requires the complainant to provide actual active consent throughout every phase of the sexual activity. It is not possible for an unconscious person to satisfy this requirement, even if she expresses her consent in advance.

\section{ANALYZING LEAF'S FEMINIST INTERVENTION}

\section{A. A Dose of Intervention}

A reading of the majority's decision provides a snapshot of a Court sure of the law of sexual assault. This is a Court who is well aware of its institutional role vis a vis Parliament, and a Court that sees itself as informed by the intervention of LEAF, but not at its command. An analysis of the intervener factums of LEAF and

\section{Ibid at para. 55}

Ibid at para. 57 citing $R v$ Cuerrier, [1998] 2 S.C.R. 371, per McLachlin J. (as she then was), at para. 52, $R$ v Jobidon, [1991] 2 S.C.R. 714, per Gonthier J. at 743 and Ewanchuk, supra note 20 at para. 31.

$43 \quad$ Ibid at para. 59.

44 Ibid at para. 60 citing $R v$ Osvath (1996), 46 C.R. (4th) 124 (Ont. C.A.), per Abella J.A.

$45 J$, ibid at para. 61.

$46 \quad$ Ibid at para. 62.

$47 \quad$ Ibid at para. 66. 
the AG of Canada, suggests that the majority relied heavily on the submissions of both interveners.

The AG of Canada in its factum made four substantive claims. It argued that consent required an operating mind, that s.273.1 is clear on the vitiation of consent, that advance consent would have deleterious impact on vulnerable groups such as women and youth (consisting mainly of women) between the ages 15-24, and that Parliament had the opportunity to turn its mind to advance consent in the passage of 273.1 and failed to act; thus the Court should fail to impose its will on Parliament. ${ }^{49}$ Similarly, LEAF provided in its factum that consent requires contemporaneous, active and revocable consent, that implied consent was untenable under Canadian law, and that advance consent nullifies the statutory protections in place for women (including s.273.2's requirement of reasonable steps for a mistake of consent defence). ${ }^{50}$

The majority clearly and forcefully adopts each of the aforementioned submissions of the interveners. The majority aligns itself with the judicial logic of restraint with respect to Parliament's agenda, and yet it never explicitly states of what the agenda consisted. Perhaps most notably, LEAF concluded its factum by noting that s. 273 of the Code had an express purpose of "respecting and protecting women's rights to equality and security of the person". ${ }^{51}$ The majority never quite reveals this to be its understanding of the Parliamentary objective. Indeed it mainly concerns itself with how an advance consent defence would upset the administrative logic of the Parliamentary agenda. Certainly, the majority was not concerned overtly in its reasons with the equality and liberty interests of women in general. Indeed, the majority takes great care in noting that any constitutional issues would be best left to be determined on another day.

This judicial turn certainly echoes the majority of the Court's approach to consent in some earlier cases. For instance, in Ewanchuk, a close reading of the majority's reasoning, demonstrates rationales that did not extend beyond statutory construction in reaching its ultimate conclusions. ${ }^{53}$ Indeed, in Ewanchuk, it is only in Justice L'Heureux-Dube's concurring opinion that one sees any comments about the nature of equality rights in the development of consent jurisprudence. ${ }^{54}$ The closest the majority in J.A. comes to extolling an equality-based intentionality is in its rejection of the de minimis non curat lex doctrine. ${ }^{55}$ The doctrine states that

48 It is also worth noting that the Court adopted many of the submissions in the Crown's factum as well (R. v JA, 2011 SCC 28 (Factum of the Appellant (Crown)). Date of Publication 2010). This analysis is beyond the scope of this paper as our more myopic goal is to consider the extent of LEAF's influence on the majority in this case.

49 AG Factum, supra note 11 at paras. , 9, 11-24, 26, 30.

50 LEAF Factum, supra note 13 at paras. 1-32.

$51 \quad$ Ibid at para. 32.

$52 J A$, supra note 1 at para. 65.

53 Ewanchuk, supra note 20 at paras. 23-67.

54 Indeed, Justice L'Heureux-Dubé begins her decision by noting that "Violence against women takes many forms: sexual assault is one of them", at para. 68, Ewanchuk, supra note 20. The ensuing "judge wars" that occurred in the press between Alberta Court of Appeal Justice McLung and Justice L'Heureux-Dubé has been the subject of much academic debate. For an excellent overview see Hester Lessard, "Farce or Tragedy?: Judicial Backlash and Justice McLung" (1999) 10:3 Constitutional Forum, 65.

$55 J$, supra note 1 at para. 63 citing Canadian Foundation for Children, Youth and the Law $v$ 
the law does not care to get involved in trifles such that mild sexual touching during unconsciousness would excuse criminal guilt (a middle ground suggested by the Crown in submissions before the Court). The majority casts aside this suggestion by writing:

Without suggesting that the de minimis principle has no place in the law of sexual assault, it should be noted that even mild nonconsensual touching of a sexual nature can have profound implications for the complainant. ${ }^{56}$

This short passage suggests that the majority had perhaps accepted the possibility of some sort of equality-based harms experienced by a complainant (as suggested by LEAF), but such a suggestion is oblique at best. The Court also alludes to an equality-based premise in its distinction between surgical consent and sexual consent. In this passage, the majority distinguishes surgical touching from sexual assault on an unconscious individual on the basis that the latter is much more likely to be informed by violated boundaries and parameters of agreed upon conduct. ${ }^{57}$ Here the majority seems to indicate the sexual consent provisions in the Code are aimed at limiting abuse, presumably and usually, from a man and exacted upon a victim whom is usually a woman. Again the assertion is tacit, and left to the reader's imagination. The bulk of the majority's prose is dedicated to abstractly upholding the democratic will of Parliament and seeing fit to preserve its intention. ${ }^{58}$ The majority's decision is so fraught with fidelity to the notion of Parliamentary intent that the decision never turns its attention to the practice of choking during sex as a component of BDSM practice. ${ }^{59}$ Certainly the issue of "breath play" was one that was raised in newspaper columns prior to the case being heard at the Supreme Court. For instance, in her column in the Winnipeg Free Press, Karen Busby wrote:

Erotic asphyxiation is extremely dangerous. There is no safe way to engage in it. Any time the brain's blood supply is cut off,

Canada (Attorney General), 2004, SCC 4, [2004] 1 S.C.R. 76, at para. 200, per Arbour J.

Interestingly, the dissenting decision does raise the equality-based development of sexual assault law. The dissent saw these concerns as irrelevant to the case since "[ $t$ ]his is not a case about a woman who said no - at any time. Rather, the complainant described herself as a willing and enthusiastic participant throughout all stages of the sexual activity in question." (Ibid at para. 112). The dissent admits that central concern in the development of the law "intended to protect women from sexual violence and to protect and enhance their freedom to choose when, and with whom, they will engage in sexual relations of their choice" (at para. 110). Thus the dissent viewed the Parliamentary intent of the law of consent as a protection against sexual violence and sexual autonomy.

59 BDSM refers to sexual practice that involves aspects of bondage, discipline, dominance, submission and sad-masochism.

60 Breath play is a term used by some who practice BDSM to indicate choking during sexual activity to enhance sexual pleasure. Busby has also noted that virtually all BDSM websites advocate for a cessation of activities upon the loss of consciousness - "Interrogating R. v J.A.: Sex, Violence and Consent", supra,note 2. For a medical explanation of erotic asphyxiation see: E L Lloyd, "Points: Hallucinations, hypoxia, and neurotransmitters" (1986) 292 Brit Med J 903. 
there is a danger of brain damage and even death. At least 1,000 Americans accidentally kill themselves each year while attempting it. Even advocates for radical personal autonomy regarding sexual practices agree all sexual activity must cease when a partner loses consciousness. Common sense dictates consent to engage in sexual activity is never present when an unconscious partner is in a potentially life-threatening situation.

The AG Factum also attempted to address the issue of breath play in terms of BDSM that the Court should consider. The AG factum noted that the use of a "safe word", a common practice in virtually all BDSM practice, is useless when a complainant is unconscious. Here the AG explains that the accused and complainant had a safe word which must suggest that unconscious sex was not contemplated at all by the parties. ${ }^{62}$ Revealingly, the LEAF factum does not address the notion of breath play, safe words or BDSM practice. Rather, the factum notes that:

[T]his is not an appropriate case for the Court to determine the precise limits of consent on every case involving any kind of bodily harm caused in the context of sexual assault. This appeal deals with intentionally strangling another into unconsciousness...sexual assault eroticizes dominance and is a crime of opportunity, women... are acutely vulnerable... ${ }^{63}$

The majority seems to have agreed and did not interrogate the notion of BDSM practice. $^{64}$ The majority, LEAF and the AG Canada all seem to assert that BDSM practice is a matter best left attended to in other cases. This suggests that BDSM practice that extends to unconsciousness is not only unlawful, but is not BDSM practice at all. Certainly, an internet search of breath play will quickly reveal that unconsciousness is not a contemplated endpoint of breath play and there is little BDSM support for the practice of unconscious sex. ${ }^{65}$ Though one could just as

61 Karen Busby, "Sexual Defence Threatens Women”, Winnipeg Free Press (6 November 2010), online: The Winnipeg Free Press, <http://www.winnipegfreepress.com/opinion/westview/sexualdefence-threatens-women-106814573.html $>$.

62 AG Factum, supra note 11 at. paras. 20-21.

63 LEAF Factum, supra note 13 at paras. 4-5. The factum in particular notes the disadvantaged positions of women who are sleeping, medicated, intoxicated, sick or disabled.

64 Ibid. LEAF relied on empirical evidence linking acts of strangulation to abusive domestic relationships: see for e.g. Lee Wilbur et al "Survey Results of Women Who Have Been Strangled While in an Abusive Relationship" (2001) 21(3) Journal of Emergency Medicine 297; and Nancy Glass et al "Non-Fatal Strangulation is an Important Risk Factor for Homicide of Women" (2008) 35:3 Journal of Emergency Medicine 329.

65 For e.g.the website Fortune-city<http://www.fortune-city.com/west-wood/carving/417/breathplay.html> states:

Some things to consider no matter what kind of method you use is how your partner will signal you if there is a problem and they can't talk. Whatever the signal it should automatically happen if they faint. An example of a signal I've used is having someone hold their hand up...or put it on my hips...or something. It has to be in a place that if they faint...the 
easily surmise that no member of a BDSM community would be willing to publicly flirt with the margins of the law in such fora.

On this reading of the majority decision, together with a review of the intervener facta, one can conclude that the Supreme Court, in majority, adopted the arguments, in part, of each intervener without overtly voicing LEAF's calls for an interpretation of the Code that is apprised of Women's equality interests. Further, the majority clearly justifies its reasons utilizing the ethics of judicial restraint. Absent in the Court's discussion is the development of the consent provisions in Canada and the development of Code provisions designed to ameliorate the disadvantages faced by complainants in sexual assault cases. The reform of sexual assault law began in the 1980s in an attempt to bring the Code into conformity with the Charter. Sexual assault became a series of graduated offences and the legislation abolished much of the evidentiary constrictions that plagued complainants. In the 1990s, after the sexual history provisions (which limited a complainant's sexual past from being presented as evidence of likely consent at trial) were held to be unconstitutional, ${ }^{66}$ Parliament re-enacted the provisions to comport with an accused's right to a fair trial, further defined consent, tailored the evidence that would be admissible in sexual assault cases, and limited the mistaken belief of consent defence. ${ }^{67}$ In 1995, after the Supreme Court heard $R . v O^{\prime}$ Connor, ${ }^{68} \mathrm{Bill} \mathrm{C}-46$ was proposed which limited the production of a complainant's personal counselling records to the defense in sexual offence cases, legislation which was ultimately found to be constitutional. ${ }^{69}$

These legislative changes, together with jurisprudential shifts, were viewed by some scholars as measures of qualified success for feminist interventions. ${ }^{70}$ Lise Gotell argues that there was a distinction between the feminist aided law reform in the early 1990s and those that occurred later in the decade. In the early 1990s, she writes, the law reform was inspired by a recognition that sexual violence was a

\section{legislative changes of note also occurred including the enactment of s.33.1 of the Code} (effectively overturning $R$. v Daviault [1994] 3 S.C.R. 63) which limited the defence of selfinduced intoxication (and automatism) in sexual assaults or crimes which threatened the physical integrity of the complainant.

70 Law Reform" in Clare McGlynn \&Vanessa Munro, eds, Rethinking Rape Law (London: Routledge, 2010), 209 at 8 [("Neoliberal Reform"]; see also Lise Gotell. "Rethinking Affirmative Consent in Canadian Sexual Assault Law: Neoliberal Sexual Subjects and Risky Women" (2008). 41 Akron L Rev 865 ["Neoliberal Affirmative"] and Lise Gotell. "The Discursive Disappearance of Sexualized Violence: Feminist Law Reform, Judicial Resistance and Neoliberal Sexual Citizenship," in Dorothy E. Chunn, Susan B. Boyd \& Hester Lessard, eds, Feminism, Law and Social Change: (Re)action and Resistance (Vancouver: University of British Columbia Press, 2007) 127 ["Neoliberal Citizen"]. 
social problem; however, by the end of the decade, the feminist interventions were recast as matters particular to special interest groups "excluded from policy networks". G1 Gotell argues that this recasting occurred as "victims rights bureaucracies" exploded across Canada focusing on the individualism of the victim instead of gendered "policy discourses". ${ }^{72}$ Simultaneously, federal funding structures for feminist organizations changed to focus on service delivery and the feminist interventions sought to rely on increasingly provincial funding structures thereby reducing the visibility and influence of these interventions. ${ }^{73}$ Prior to the release of J.A., Gotell argued that:

Canadian judicial discourses consolidating an affirmative consent standard reinforce a decontexualized construction of sexual assault. Emphasis is placed on discrete sexual transactions, consent-seeking actions and the quality of agreement. And while valuable in focusing attention on the demonstration of positive consent, sexual violence is atomized; its manifestations and consequences are never collected, never considered in a context where sexual assault is a mechanism for sustaining gendered power relations. ${ }^{74}$

Gotell ties this conclusion to the notion that the shift in Canada of decontextualizing consent is a risk-management strategy of governmentality ${ }^{75}$ that those "subjects who diligently practice sexual safekeeping" are managed through their prudential conduct rather than the production by centralized government of policy to manage the "social" problem of "sexual violence". "Some

71 Gottel, "Neoliberal Reform" ibid at 8; Gotell, "Neoliberal Citizen", ibid.; Gotell, "Neoliberal Affirmative", ibid. Gotell relies heavily on Carol Smart. Feminism and the Power of Law (London: Routledge, 1989); Carol Smart. Law, Crime and Sexuality (London: Sage, 1995) and Laureen Snider, "The Potential of the Criminal Justice System to Promote Feminist Concerns" (1990) 10 Studies in Law, Politics and Society 143.

72 Gottel, "Neoliberal Reform" supra note 70.

73 Gottel, "Neoliberal Reform" ibid at 8-9; Melanie A. Beres, Lise Gotell \& Barbara Crow, "The Perils of Institutionalization in Neoliberal Times: Results of a National Survey of Rape Crisis and Sexual Assault Centres" (2009) 34 Canadian Journal of Sociology 135.

74 Gottel, "Neoliberal Reform", supra note 70 at 14.

75 Michel Foucault's explication of governmentality is beyond the scope of this brief paper. The concept speaks to an era of neo-liberal values where governance is shifted to the margins, individuals and administrative entities are given faux power to govern themselves under a ruse of liberty, and in which the realm of the sovereign power through delegation is massively expanded and even more intrusive. For introductory readings see: Michel Foucault, "Governmentality" in Graham Burchell Colin Gordon \& Peter Miller eds, The Foucault Effect (Chicago: University of Chicago Press, 1991); Mitchell Dean, Governmentality: Power and Rule in Modern Society (London: Sage Publications, 1999); Nikola Rose, Pat O'Malley\& Mariana Valverde, "Governmentality" (2006) 2 Annual Review of Law and Social Science 2; Nikolas Rose and MarianaValverde, "Governed by law?" (1998) 7 Soc \& Leg Stud 541.

76 Gottel,"Neoliberal Reform", supra note 70 at 15 . Gotell further elaborates at 10 that: What Canadian feminists achieved in rewriting sexual assault legislation was complex, inserting recognition of sexual autonomy and gender equality into a criminal legal framework defined by individual responsibility and punishment. Though revised Criminal Code provisions provide the architecture of an affirmative consent standard, their interpretation by a wide variety of actors in the criminal justice system occurs in the context of 
critical scholars go further still, seeing a fundamental disconnect between feminist advocacy and lobbying in the name of criminal sanction. For example Lessard asks "is a commitment to fundamental justice which integrates both liberty andality values possible in a system that relies so centrally on punishment and savage methods of correction, and that demands conformity with a rigid and oversimplified account of state and citizen, victim and offender, complainant and accused?" Kent Roach has argued persuasively that reforms in sexual assault law were somewhat convenient for the government as the reforms advanced the politics of law and order, a matter that is met with a degree of popular support, while simultaneously placating the concerns of feminist activism groups such as LEAF. $^{78}$

Other scholars such as Benedet and Grant have argued that current Canadian sexual assault law often marginalizes the context of specific vulnerabilities of women in favour of privileging liberty interests of the accused under the guise of the autonomy of the complainant. ${ }^{79}$ Thus compliance of the complainant is often, according to this argument, recast ironically not as domination or coerced behaviour, but as free choice.

There are those who see a more optimistic development in sexual assault law in the last ten to fifteen years. Elaine Craig argues that the law of consent in sexual assault does not unjustifiably "criminalize the progression of intimate behaviour between genuinely consenting adults"; she notes that in situations of legitimate confusion between partners as to consent, the courts "apply a communicative concept of consent that can accommodate the diversity and specificity with which sexual interactions tend to occur". ${ }^{80}$ Craig argues that in its decisions dealing with sexual assault, the Court has allowed for an interpretation of sexuality that is, more than ever apprised, by respect for sexual integrity - the Court is adopting jurisprudential techniques that "reflect an approach that is concerned more with power, relationships, equality and sexual actors than with sexual arousal and sexual acts." ${ }^{81}$ In the development of the Canadian sexual assault legislative and jurisprudential changes, Craig argues that the Court is gradually beginning to see sexual integrity as not just ''freedom from' bodily invasion but also 'conditions for'

an official silence. Without external political discourses recognizing sexual assault as a systemic problem, the tendency of criminal law toward decontextualization and individualization holds sway. Lessard, supra note 54 at 72; For a more critical feminist perspective see also Laureen Snider, "Feminism, Punishment and the Potential of Empowerment" (1994) 9 CJLS 75.

78 Kent Roach, Due Process and Victims' Rights: The New Law and Politics of Criminal Justice (Toronto: University of Toronto Press, 1999). See pages 151-192 for a more detailed discussion of this point.

79 Janine Benedet \& Isabel Grant, "Hearing the Sexual Assault Complaints of Women with Mental Disabilities: Consent, Capacity and Mistaken Belief" (2007) 52 McGill LJ 243 ("Mental"); Benedet and Grant's work is informed by Catherine MacKinnon's work in the area of sex and the law. See Catharine A. MacKinnon, Feminism Unmodified. (Cambridge, MA: Harvard University Press, 1987) and Catharine A. MacKinnon, Only Words. (Cambridge, MA: Harvard University Press, 1993). See also Melanie Randall, "Sexual Assault in Spousal Relationships, 'Continuous Consent', and the Law, Honest but Mistaken Judicial Beliefs” (2010) 32:1 University of Man LJ 144.

80 Craig, "Ten", supra note 20 at 268.

81 Elaine Craig, Sex And The Supremes: Towards A Legal Theory of Sexuality (Dalhousie University: Halifax, Nova Scotia, 2010), online: Dalspace, < http://dal-space.library.d-a1.ca/handle/10222/12997> at 155 [Supremes]. 
an integrated, coherent and functional sexuality.," Craig writes that the development of the law must:

[T]ake into account preservation of sexual self-esteem, sexual awareness, sense of sexual self, and ability to achieve sexual pleasure or benefit. It must develop language and concepts that accommodate the 'conditions for' sexual integrity.

Thus in these diverse feminist (and in some cases non feminist) interpretations of the development of the law of sexual assault one sees apposite but simultaneously contradictory summations of the law. These accounts see the legislative changes in the 1990s as generally beneficial to the feminist interventions, seeing useful understandings of sexuality as the Court began to become aware of the gendered nature of sexual violence in Canada. Gotell then sees a shift in the latter half of that decade to legal approaches to sexual violence that delegate the responsibility of sexual assault to victims themselves, that devolve the management of victimization to front line social service work, and which disciplines complainants' sexual conduct through, in part, the discourse of the Court. Craig on the other hand sees a Court that has been developing a notion of sexual integrity that extends beyond the corporeal into understandings of power dynamics and relational complexities that exist in social and sexual interactions. Benedet and Grant see the law's failure in ameliorating the social conditions of women who experience sexual violence. Lessard and Roach question the feminist interventions in the law of sexual assault as ironically supportive of law and order policies. The implications for feminist interpretations of the law of sexual assault seem confounding.

It is unsurprising then that the majority of the Supreme Court of Canada would fail to give explicit effect to an equality-based rationale (as suggested by LEAF) in its deployment of the "no advance consent" rule in J.A. It is also understandable that the Court would not recount the political revolutions in sexual assault law in the 30 years preceding its decision. In particular, the legislative and jurisprudential changes in the 1990s were complex, contested and viewed multivalently amongst scholars. It is likely, in this respect, that the Court found it much easier to place its logic in the terrain of judicial restraint and fidelity to Parliamentary intent. Given that a "no advance consent rule" could be cast favourably by those who view sexual assault law as an exercise in governmental responsibilization (such as Gotell) or for those who see the potentialities in an embrace of sexual integrity (such as Craig), an appeal to judicial restraint would provide some red meat to many feminist callers. For example, Gotell could view the decision as a slight move away from the responsibilization of the victim $-\mathrm{a}$

82 Ibid at 177; Craig elaborates further on the "pleasure principle" in Elaine Craig, "Re-interpreting the Criminal Regulation of Sex Work in Light of R. c. Labaye" (2008) 12:3 Can Crim L Rev 327 ["Sex Work"]. This principle is also developed in the work of Brenda Cossman, "Sex and the Unconscious (No, We Aren't Speaking of Freud)" online: Mark S. Bonham Centre for Sexual Diversity Studies <http://www.uc.utoronto.ca/content/view/1114/2666/ > ["Freud"]. The pleasure principle as a laudatory affirmation of sexuality in Canadian society would come under scrutiny during an unconscious sexual encounter because the complainant in such cases would not experience anything at all

83 Craig, ibid at 172 
brief moment where the Court places the responsibility of sexual assault in the hands of the state and the accused when a complainant is unconscious (Benedet and Grant would likely concur). Craig would argue that the decision, in placing the risk of engaging in unconscious sex squarely at the feet of an accused, and by respecting the operating mind principle, favours the sexual integrity of women. In either case, the decision in J.A. attempts to provide something for everyone.

Even in the early days following the decision, some interesting tension is beginning to emerge. Certainly, some media response has painted the decision in a less than favourable light. Journalist Ian Mulgrew takes umbrage with Professor Sheehy's (one of LEAF's counsel in the case) portrayal of the J.A. decision as a victory for women:

While Sheehy concedes this judgment means couples now risk a criminal charge for a caress during sleep, she falls back on a pitiful argument: Yes, but the courts won't hear such cases. Would anyone level such charges, would police investigate them, would the Crown prosecute them, who would testify, she responded with incredulity.

Similarly, Brenda Cossman immediately reacted to the decision with a stunning rebuke. Cossman holds out the possibility that consensual unconscious sex is possible. She writes that the decision in J.A. is:

[T] aking a consensual sexual practice, a consensual sexual fetish and saying that it is unacceptable. It is saying that this is simply not the sort of thing that a person should be allowed to consent to. It is analogous to (although the Court refused to engage with the related issues) the legal regulation of BDSM: the law has held that a person cannot consent to an assault. Indeed, I would argue that erotic asphyxiation is a subset of BDSM practices: consensual sexual practices outside of the norm, consensual sexual practices to which individuals are not by law allowed to legally consent. ${ }^{85}$

The Court in crafting a majority decision that comports with many feminist rationales as well as affirming its own judicial restraint may have anticipated some critique in the journalistic media but it likely was not expecting any critique from notable feminist scholars such as Cossman. Clearly, these are the early days of fallout after the J.A. decision, but so far the uneasy coalition of ideologies holds.

Uneasy coalitions of ideologies are not new phenomenon in the Canadian development of sexuality and the law. In the final pages of this paper, we review one such example of converging ideologies and ask whether that narrative holds any consequence in the wake of J.A.

84 Ian Mulgrew, "Ruling on Sexual Assault has Troubling Implications", Winnipeg Free Press (9 June 2011), online: Winnipeg Free Press, <http://www.winnipegfreepress.com/opinion/westview/ruling-on-sexual-consent-has-troubling-implications-123531529.html $>$ Republished from the Winnipeg Free Press print edition June 9, 2011 A15.

85

Cossman, "Freud", supra note 82 


\section{B. Converging Ideologies}

One moment of interesting ideological convergence occurred in the infamous R. $v$ Butler case. ${ }^{86}$ In this case, the majority of the Supreme Court of Canada developed a test for determining criminal obscenity and indecency in Canada by reference to the community standards of tolerance of harm test. The Court, in majority, formulated that certain types of obscenity would be more likely to be considered harmful in Canada than others. Harmful (and therefore criminalized) obscenity would consist of sexual activity that was explicit and violent or which was likely to degrade and dehumanize its participants (if the risk of harm was substantial); sexual expression that was explicit but without violence or degradation of dehumanization (and not involving children) would not be obscene. $^{87}$

Scholars have noted that the development of this legal standard was indeed controversial, despite that the Supreme Court had limited feminist intervention before it, in LEAF's factum. ${ }^{88}$ LEAF argued that pornographic materials usually produced harm, and the Supreme Court produced a legal standard that generally agreed with LEAF's contention. Following the case:

The divide that ensued amongst certain feminist scholars was indicative of what some have described as the Canadian followup to the "sex wars" - a division between "those who framed sexuality primarily as a site of danger and oppression for women and those who saw sexuality more ambivalently, as also a site of pleasure and liberation."

The division ensued mainly through the activism of queer ${ }^{90}$ theorists and reached its zenith in the Little Sisters ${ }^{91}$ litigation where the Supreme Court was faced with examining the constitutionality of the administration of customs policy that appeared to target queer bookshops in a discriminatory fashion by withholding certain publications at the border. While arguments to alter the Butler standard to more fully account for queer erotica failed, the case did inspire "a vibrant and multivalent discussion about the efficacy of the Butler test in the context of expression that had impacts on women, children, alternative sexualities, and society at large".

The debates amongst and between feminist scholars in the context of obscenity and indecency laws are well interrogated in the literature. ${ }^{93}$ Perhaps the most

\footnotetext{
86 [1992] 1 S.C.R. 452 [Butler].

87 Ibid at 485.

88 Richard Jochelson, “After Labaye: The Harm Test of Obscenity, the New Judicial Vacuum, and the Relevance of Familiar Voices" (2009) 46 Alta L Rev 741 at para 2.

89 Ibid at para 2 citing Brenda Cossman, "Sexuality, Queer Theory, and 'Feminism After': Reading and Rereading the Sexual Subject" (2004) 49 McGill LJ 847 at 851.

90 We use the term to refer to any and/or all of the following: people who identify themselves as gay, lesbian, bisexual, questioning, transgendered, transsexual, two spirited, or intersexed.

912000 SCC 69, [2000] 2 S.C.R. 1120 [“Little Sisters].

92 Jochelson, supra note 88 at para. 3.

93 For a book length articulation see Richard Jochelson \& Kirsten Kramar. Sex and the Supreme Court: Obscenity and Indecency Laws in Canada. (Nova Scotia: Fernwood Basics, 2011); see
} 
compelling arguments against the contention that the Butler decision was an absorption of a feminist equality-based premise was that "Butler merely provide[d] a new feminist language to legitimize and modernize what is really an old conservative, moral agenda". "For those who subscribed to this claim, the legal test in Butler represented a convergence between conservatism and certain feminisms that that viewed sex as "bad, physical, shameful, dangerous, base, guilty until proven innocent, and redeemable only if it transcends its base nature." normalize and regulate good sexual subjects." "When the Court began to interrogate the harms of queer erotica in Little Sisters this conservatism was also "concerned about harms to the unwitting passerby and a multitude of other viewpoints - it represent[ed] a dilution of the original premise of concern for women. ${ }^{97}$

The debate between feminists who viewed the Butler standard as disguised moral conservatism as opposed to an adoption of feminist equality-based values remained unresolved, and ultimately (and perhaps not coincidentally) the Supreme Court retired and refined the test in its Labaye ${ }^{98}$ and Kouri ${ }^{99}$ decisions (known colloquially as the Swinger's cases). The Court articulated a new harm test for the determination of obscenity and indecency, one that has created more questions for feminist scholars than answers. ${ }^{100}$

The feminist interrogations following the Butler case provide an unsatisfactory cautionary tale of the converging analytics of some feminisms and conservative ideologies. Some continued to argue that "Little Sisters, like Butler, marked 'an important step in the decriminalization of sexual expression' despite that it said "little about the benefits of sexual speech"" ${ }^{101}$. Others simply contended that the Court, despite its newly formulated harm test, was mainly concerned with "a sexual voyeur" who is constructed "negatively - a victim and an offender". Feminist debate remained ultimately fragmented and unresolved. Indeed between the Butler and Little Sisters cases, LEAF changed its strategy finding a middle ground in modifying its contention that most pornography was harmful, allowing that in the context of queer erotica, pornography could be liberatory and

also Brenda Cossman et al, eds, Bad Attitude/s on Trial: Pornography, Feminism and the Butler Decision (Toronto: University of Toronto Press, 1997) [BA].

Lise Gotell, "Shaping Butler: The New Politics of Anti-Pornography" in BA, ibid 48 at 99.

Ibid at 107.

Ibid at 98-99.

Jochelson, supra note 88 at para. 26.

R. v Labaye 2005 SCC 80, [2005] 3 S.C.R. 728 [Labaye].

R. v Kouri 2005 SCC 81 [Kour].

100 The degree to which the new harm test is "feminist friendly" is explored in Jochelson \& Kramar, supra note 93 and also in Craig, "Sex Work", supra note 81.

101 Jochelson, supra note 88 at para. 33 citing Karen Busby, "Little Sister's v Canada: What Did the Queer-Sensitive Interveners Argue about Equality Rights and Free Expression?" in Brian Burtch \& Nick Larsen, eds, Law in Society: Canadian Readings, 2d ed. (Toronto: Thompson Canada, 2006) 4 at 10, 14 and 15.

102 Brenda Cossman, "Disciplining the Unruly: Sexual Outlaws, Little Sisters and the Legacy of Butler" (2003) 36 UBC L Rev 77 at 92 ["Unruly"]. 
supportive of women's equality. ${ }^{103}$ Whether LEAF ever achieved a type of equality for women in the context of obscenity and indecency law remains clearly unresolved, a matter complicated by the Court's decision in 2005 in Labaye and Kouri.

\section{Parallel Universes but a World Apart}

The J.A. case also finds LEAF in the throes of interesting convergences. This time the convergence is between LEAF's argument that equality and liberty for women requires contextual analysis of women's lived realities, and the Courts contention that allowing an advance consent rule would do damage to Parliament's clear intent. This time the equality-based premise of LEAF aligns not with a Court which imported a moral conservative agenda, but rather a Court which used judicial restraint or judicial conservatism as an interpretive tool to ground its decision. Here the Court has taken great care to ensure it was not derogating from the will of the electorate by subverting legislative aims. ${ }^{104}$ Often such claims are buttressed by claims of moral universality, permanence and societal consensus. ${ }^{105}$

Such universality stands in sharp contrast to the politics of recognition often advocated by feminist scholars such as Benhabib and Young. ${ }^{106}$ Briefly, such claims for recognition argue that rather than conceiving of a victim, as an abstract, rights bearing subject or a 'generalized other', richer discussions take place when an analysis 'concretizes' the nature of the legal subject. That is, an analysis rich in context and multivalence, provides for more fulsome socio-legal discussion than abstract discussions about hypothetical subjects.

The arguments advanced by LEAF and supported by Gotell, Benedet and Grant in the context of sexual assault law, support a certain type of universalization of the sexual subject. These arguments rely on the notion that compliance disguises as consent in cases such as J.A. ${ }^{107}$ These arguments tacitly suggest, that the complainant did not consent in this case, despite her uncontradicted testimony at trial that she did consent to the sexual activity in question. Gotell seems to suggest that the individuation of a complainant's testimony in such cases represents a "neo-liberal" ensconcement of the victim as a

103 Karen Busby, "The Queer Sensitive Interveners in the Little Sisters Case: A Response to Dr. Kendall" in Todd G. Morrison (ed.), Eclectic Views on Gay Male Pornography: Pornucopia (Binghampton, New York: Harrington Park Press 2004); reprinted (slightly revised) in Brian Burtch and Nick Larsen, Law in Society: Canadian Readings (2nd Edition) Toronto: Thomson Nelson 2006); Online: <http://www.umanitoba.ca/ law/newsite/Courses/Busby/Const/littlesisters.pdf> [Busby, "Interveners"]; Jochelson and Kramar, supra note 93 at 48.

104 FL Morton and Rainer Knopff, The Charter Revolution and the Court Party (Peterborough: Broadview Press, 2000) at 34-53; Christopher P. Manfredi, "Judicial Review and Criminal Disenfranchisement" (1998) 60 The Review of Politics 279 at 285-287; FL Morton and Rainer Knopff, "Permanence and Change in a Written Constitution: The 'Living Tree' Doctrine and the Charter of Rights" (1990) 1 SupCtLRev 531 at 539-545; Wil Waluchow, "Constitutions as Living Trees: An Idiot Defends" (2005) 18 CanJL\&Juris 207 at para. 35.

105 James B Kelly and Michael Murphy, "Confronting Judicial Supremacy: A Defence of Judicial Activism and the Supreme Court of Canada's Legal Rights Jurisprudence" (2001) 16 CJLS 3 at 8; Manfredi, ibid:; Morton \&Knopff, ibid at 540-1.

106 Seyla Benhabib. Situating the Self: Gender, Community and Postmodernism in Contemporary Ethics (New York: Routledge, 1992) at 158-9; Diana Young, "Claims for Recognition and the Generalized Other: The Reasonable Person and Judgment in Criminal Law" (2008) 23 CJLS 15 at 16.

107 Benedet \& Grant, supra note 79 at 270. 
rational actor in a free market foisted upon individual sexual actors - unwitting agents of the governmentalities of the victim's rights movements, these sexual actors are agent-less automatons reacting to the market forces that encourage their sexual compliance. In Gotell's estimation, this interpretation of a complainant's state of being is less rich in context than equality-based assessments. A Benhabibian interpretation might offer a counterpoint to this contention recognition would likely require a more fulsome inquiry of the complainant's experience of the sexual conduct and attempt to provide more points of contact between the victim and the law as opposed to a universalizing feminist understanding of consent.

On this point, the Court's judicial conservatism aligns with a type of feminist universalism. The principle of the operating mind and LEAF's feminist interventions importing equality values align around the proposition that an unconscious actor cannot provide advance consent to sexual contact The Court understands this as the will of Parliament, and understands consent as a quasicontractual matter, requiring conscious will. LEAF's conception of consent is apprised of the notion that advance consent would problematize notions of sexual integrity, fail to live up to the promise of women's sexual pleasure, and further reify the responsibilization of the victim. This is an alignment between judicial conservatism and feminists analytics that has been relatively rare in the jurisprudential history.

Yet, unlike the Butler epoch, it is less than likely that we will see competing feminist interpretations emerge in the yet to be formed academic literature. This is perhaps the case, because unlike Little Sisters, we do not find ourselves in a situation where a mobilized community contests the presuppositions of consent articulated by the Court and LEAF in the J.A. case (for instance, queer communities were moved by Customs' behaviour in Little Sisters).

The politics of recognition seem less critical for groups that operate on the fringes of sexuality and who flirt with the margins of sexual assault law. ${ }^{108}$ Perhaps this is the unstated logic of the J.A. case. A rule against advance consent offends little in the way of identity politics, satisfies many iterations of feminist equality claims, aligns with judicial politics of restraint towards Parliament, and lastly, aligns with the purported dangers of asphyxiation play during sex (a matter left uninterrogated by the Court). A rule against unconscious sex thus satisfies many political rationales in one effective and blunt technology. ${ }^{109}$ The only clear voice

108 Cossman, supra note 85, writes:

The question of consenting to sex after erotic asphyxiation may not be an issue affecting a lot of folks. The majority of the Supreme Court may think that it helping more women than it is hurting by putting this practice beyond the realm of consent. I disagree. I aspire to the ideals of a sexual democracy where were respect the rights - and consensual choices of sexual minorities (defined narrowly as consensual adults engaged in sexual practices with other consensual adults...no pedophilia or bestiality slippery slopes here). It's a simple concept, really. Yes means yes, no means no. Maybe one day, the courts will get it.

109 The dissenting reasons in J.A. are matter best left for another paper. It is interesting that the dissent raises a less blunt mechanism of mediating the evidentiary risks in cases of advance consent and unconsciousness. The dissent provides at para. 141, supra note 1, that: "If Parliament thinks it necessary to address the evidentiary concern, it may do so by more appropriate means. For example, it can satisfy that perceived need by enacting an evidential presumption of nonconsent in favour of the Crown where it has proved that the accused engaged in sexual contact with an unconscious person." 
left out of the political calculus is the voice of the complainant herself.

Perhaps this omission can be explained by greater appeals to universal equality or judicial conservatism in general. It is conceivable that the voice of complainant is less important to the Court in the context of 'less worthy' offenders. Cossman notes that the accused in J.A. had twenty-three previous criminal convictions, and three for domestic assaults - two against the complainant in this case. ${ }^{110}$ This context of domestic abuse was not explored by the Court and would be of limited probative (and indeed, to the accused, highly prejudicial) value in the context of the criminal law. This is evidence that a Court is largely prohibited from using to contextualize sexual assault in most cases. Yet certainly members of the Court would be aware of this history. In this situation it is perhaps understandable that a Court, and the feminist interventions before it, would view apparent consent as illegal compliance. These are certainly compelling circumstances in which to ignore calls to give more voice to the complainant. Certainly calls for recognition in such cases have been critiqued in the academic literature. Indeed in a larger political-economic assessment, Fraser writes of the limited value of the politics of recognition:

Claims for the recognition of difference now drive many of the world's social conflicts, from campaigns for national sovereignty and subnational autonomy, to battles around multiculturalism, to the newly energized movements for international human rights, which seek to promote both universal respect for shared humanity and esteem for cultural distinctiveness. They have also become predominant within social movements such as feminism, which had previously foregrounded the redistribution of resources. To be sure, such struggles cover a wide range of aspirations, from the patently emancipatory to the downright reprehensible (with most probably falling somewhere in between). Nevertheless, the recourse to a common grammar is worth considering. Why today, after the demise of Soviet-style communism and the acceleration of globalization, do so many conflicts take this form? Why do so many movements couch their claims in the idiom of recognition? ${ }^{111}$

This same claim has resulted in some calling for a movement away from identity politics towards a new system of ethics. Such scholars see unfettered recognition as a reformulation of systemic inadequacies as personal crises; these scholars advocate for a return to more abstract principles of justice, politics and ethics. ${ }^{112}$

In this context then one could certainly understand the interesting allegiance between LEAF's feminist interventions and the Court's judicial conservatism in $J . A$. Both are striving for universalism in a sea of sexual conduct which is fraught

110 Cossman, supra note 85.

111 Nancy Fraser, "Rethinking Recognition” (2000) 3 New Left Review, online: New Left Review<http://www.newleftreview.org/?view=2248> at para. 2.

112 Slavoj Zizek, First as Tragedy, Then as Farce (London: Verso Books, 2009); Slavoj Zizek, In Defense of Lost Causes (London: Verso Books, 2008). 
with identity politics, multiplicities of viewpoints, and very little in the way of opposition. The case represents a particularly and peculiarly opportune time for these converging ideologies.

\section{CONCLUSION}

The decision of the majority of the Supreme Court in J.A. makes clear the promise of the Court's earlier decisions in cases such as Ewanchuk 1999. The majority draws on its earlier denunciation of the doctrine of implied consent to sexual assault and its earlier conclusions on the mistake of consent defence to buttress its claim that an unconscious party can never consent to sex. The Court further anchors this assessment in the logics of judicial restraint and conservatism toward Parliamentary intent.

The decision is an interesting moment of convergence between judicial conservatism and claims by groups such as LEAF that a "no advance consent" rule would fulfill the equality guarantees of the Charter for women. This feminist claim, and its convergence with the majority's decision evoke a similar convergence between feminist interventions and moral conservatism while the Court was forming its post-Charter obscenity and indecency jurisprudence. There, a multivalent sexual debate opened up between feminisms which remains largely unresolved in the academic literature.

Those who might problematize our findings in this paper, would point out that in Ewanchuk, like J.A., the majority was relying on judicial conservatism and statutory interpretation; however, they might argue, that the statutory framework was itself informed in its drafting by LEAF's influence. ${ }^{113}$ We would agree that certainly in Ewanchuk, where the majority of the Court did not overtly give voice to a feminist premise in its decision, it did rely on legislation that occurred in the context of wide reaching lobbying strategies by LEAF. However, the decision in $J . A$. was much starker in terms of the limited nature of the issue. The majority decision in J.A. occurred in the simple context of whether consent for unconscious sexual conduct could be obtained in advance of the acts. Unlike Ewanchuk, the Court did not have to clarify the actus reus, mens rea, and excuses available in cases of sexual assault. The implicit appeal to feminist influence in J.A., in the result was, thus, even less significant than the tacit influence in Ewanchuk. Indeed, in making the ultimate determination, the majority in J.A. uses a doctrine of plain meaning to elucidate Parliamentary intent in the absence of Hansard or other context informing evidence. Plain meaning statutory construction is decontextualized analysis that usually is not associated with equality seeking advocacy. Whatever, influence LEAF's equality concerns in Ewanchuk may have been, the result meted out by the majority in J.A., and supported by LEAF, is clearly not apprised by the quantum of fulsome influence that LEAF had (and that Parliament considered) in the drafting and litigation of the entire sexual assault scheme interpreted and applied in cases like Ewanchuk.

113 For example, in Bill C-72 which amended the self-induced intoxication defence in sexual assault, the preamble references s. 15 of the Charter, and recognizes "that violence has a particularly disadvantaging impact on the equal participation of women". See Bill C-72, An Act to Amend the Criminal Code (Self-Induced Intoxication), $1^{\text {st }}$ Sess. $35^{\text {th }}$ Parl., (assented to $13^{\text {th }}$ July, 1995), online: Parliament of Canada <http://www.parl.gc.ca/HousePublications/Publication.aspx?Doc$\mathrm{Id}=2328375 \&$ File $=16 \&$ Language $=\mathrm{e} \&$ Mode $=1>$. 
Indeed, the result in J.A. is much more similar to moments of convergence between judicial conservatism and feminism as in cases such as Butler. In Butler, the Court's conception of the "proper functioning society" apprised of constitutional values happened to align with LEAF's conception of equality in a singular instance. Similar ensuing debate (like the "sex wars") is unlikely to develop in response to J.A. because the universalism of the Court seems to align with a universalist feminist understanding of equality values (at least in the context of sexual assault) as well as calls from certain feminist circles for an ideal of sexual integrity to inculcate the Court's reasoning. In addition, relatively few in the BDSM or "other" communities are likely to argue for (or perhaps speak up for) a species of sexual conduct that flirts flagrantly with established norms of sexual conduct.

Nevertheless, jurisprudential history and feminist interventions provide a cautionary tale of universalism of feminist discourse aligning with conservatism on the bench, and it is a convergence that is worth noting and assessing. Further, the growing skepticism on the academic left as to the efficacy of the politics of recognition provides a further lack of impetus to imagine feminist disenchantment with the "no advance consent" rule. Yet one is still moved by those highly contextualized debates following the Butler "sex wars". Gotell writes of the struggles that LEAF faced in confronting such universalism in the 1990s:

... the essentialism that had grounded its earlier discourse was profoundly challenged as LEAF underwent an "internal struggle to be more responsive to the needs of all women." In 1992, LEAF sponsored a major symposium, the central themes of which were an exploration of "women's diversity" and the need to "widen the circle." This symposium provided a space within which aboriginal women, women of colour and women with disabilities could demand a feminist equality theory that would ensure that "issues of race, heritage and disability are never "add-ons" to the experience of sexism." The often fraught conversations that emerged revealed deep dissatisfaction with the feminist legal project as it had been constructed by LEAF. The multiple concerns voiced underlined the narrowness of feminist struggles built on an abstracted and singular women's experience.

In J.A., LEAF may have found an issue that it considers to be univalent, abstractable and universal. LEAF has identified an essential truth of its activist politics and its feminist interventions. Unconscious women cannot consent to sex, no matter what the complainant may say or believe. Perhaps some essentialism exists on a narrow issue in the context of feminist intervention in sleeping/unconscious sexual assault cases. Perhaps this is an issue upon which a conservative bench and most Canadian feminists can agree. Perhaps there is some

114 Lise Gotell, Book Review of Feminist Activism in the Supreme Court: Legal Mobilization and the Women's Legal Education and Action Fund by Christopher P. Manfredi (2004) 30 Queen's LJ 883 at para. 7. 
essentialism left (and right) in Canadian politics for feminist activism. Essentialism makes for strange bedmates. 